\title{
EQUiLIBRIUM
}

Quarterly Journal of Economics and Economic Policy

2015 VOLUME 10 ISSUE 1, March

p-ISSN 1689-765X, e-ISSN 2353-3293

www.economic-policy.pl

Masiukiewicz, P. (2015). Doctrine of Public Good in Banking Versus State Intervention. Equilibrium. Quarterly Journal of Economics and Economic Policy, 10(1), pp. 55-67, DOI: http://dx.doi.org/10.1 2775/EQUIL.2015.003

Piotr Masiukiewicz

Warsaw School of Economics, Poland

\section{Doctrine of Public Good in Banking Versus State Intervention}

JEL Classification: $G 01 ; G 21 ; H 41$

Keywords: bankruptcy; bank; crisis; financial institution; public good

\begin{abstract}
This article has the following thesis: changes in banking and the role of banks in real economy in recent years give an argument for treating banks as a public good. Banks received great support from governments as a result of the subprime crisis. G-20 and European Commission recommended new regulations for this sector after the crisis.

As a consequence of banking development, more than $90 \%$ of the population use banking services in many countries. New social functions of banks have appeared. Doctrines about recovery and government support for banks were changed in parallel (e.g. LoLR). Presently, there are some arguments for recognition of public good doctrine in banking such as: a very big area for state regulation, state banking supervision, state system of deposits insurance, realization of task delegated by the state, social responsibility of banks and others.

These arguments confirm that banks' activity has a particular importance for the society and the economy, and would be public good.
\end{abstract}

(C) Copyright Institute of Economic Research \& Polish Economic Society Branch in Torun Date of submission: December 16, 2014; date of acceptance: February 15, 2015

* Contact: piotr.masiukiewicz@wp.pl, Institute of Value Management, Collegium of Business Administration, Warsaw School of Economics, ul. Madalińskiego 31/33, 02-544 Warsaw, Poland 


\section{Introduction}

Presently, financial services have become common; for those who do not have access to them there are programs for counteracting financial exclusion. The new considerations for banking, new risks and new dimension for potential financial crises create the question whether banking has become a public good. State intervention on a great scale during the subprime crisis indicates that the governments and international institutions treat banking as a special good. Not a single bank went bankrupt in Europe during last crisis.

Answers to the following questions seem to be important from the point of view of a banking company: what criteria should determine the public nature of financial services; what can be treated as a public good in banking; should banks assume receiving public help in the event of crisis? Presently, everyone agrees: a bank was and still is an institution of public trust.

The goal of this article is to prove that present banks should be treated as a public good.

\section{Methodology of the Research}

In this paper, the following scientific methods were used: national and international literature analysis, statistical analysis, comparative analysis and legal analysis.

The author used own earlier researches and analyzes concerning state intervention in banking crisis (Masiukiewicz, 2009; 2010a; 2010b; 2013b).

\section{Public Goods - Concepts, Definitions, References to Banking}

A good is defined as anything to which one can assign a positive value and at the same time is a value itself. (Krajewski \& Banajski, 1996) Different definitions of a good in the general social meaning appear in literature: common good, public good, impure public good, global public good, regional public good - in opposition to them there are private goods and so called club goods. Common and public goods may be considered as the same.

J. M. Buchanan named a public good as a good that has two characteristics from the economic point of view (Buchanan, 1968): 
- it is a non-rivalry good - meaning that from the moment it is created and available, it can be consumed by others without incurring any additional cost to anyone,

- it is a non-excludable good - meaning that the potential clients cannot be excluded from its consumption.

Originally the public goods were associated with the ones financed (created) by the State; presently associating the terms such as subsidized, free and public goods is not justified. Some supporters of the public goods theory think that creation of public goods may successfully happen in the private sector, yet in the majority's opinion those goods are created thanks to the State's activity (Musgrave, Samuelson) (Fijor, 2011).

P. Samuelson defines the current shape of the public goods concepts; they mean that there is no rivalry expressed by the joint delivery of a good and ineffectiveness in attempts to exclude anyone from its consumption (Samuelson, 1954).

The public goods issue has been present in the economic literature for a century; national currency and stable prices are considered to be public goods. In J.K. Solarz's opinion, today "there's a space for dialogue about public goods in financial sector instead ruling of the market or the State". The thesis presented as early as in 1992 by G. Corrigan: banks are perceived not only as public trust institutions, but even broadly as a public good; therefore, the whole society should bear the costs associated with it (system risk is the whole society's risk) - caused lots of discussion and criticism (Corrigan, 1992).

J.K. Solarz created a typology of financial services as public and private goods. (Solarz, 2008, p. 159) The purposefulness of such classification for the policy towards banking is important and necessary, even though assignment of goods to particular types is questionable. However, one should consider the volatility of the matter; for instance the ongoing democratization of brands. In the author's opinion, blurring in practice the distinction between public and private goods in financial sphere causes theoretical disputes around that who is to blame for market or state inefficiency; therefore an intermediate category of impure public goods is growing (Solarz 2008, p. 158).

It should be considered what may and ought to be a public good in banking. A few options may be mentioned here:

- the whole banking industry (loans and deposits institutions),

- only universal banks,

- only the safety of client deposits,

- only the retail customer's operations or selected products, 
- system stability or institutional system of its protection (e.g. Financial Safety Net in the EU),

- common and small scale operations (e.g. up to the amount of 50 thousand EUR in the EU within the framework of deposit insurance).

Recognition of a bank as a public good is a short way of thinking that financial services which are rendered under the state control are important, of course. They aren't "clear" public goods. - Financial excluding shouldn't take place because of fundamental social reasons with normative approach to this problem (McNutt, 2002).

In W. Szpringer's opinion, the public good category may be applied to the banking system, not to the individual bank that may go bankrupt after all (Szpringer, 2001, p. 11).

A. Greenspan treated financial stability as a public good. He stated that the LoLR function is and will be essential because "the markets mostly work efficiently, but from time to time they collapse. When it happens the State's intervention is necessary in order to preserve stability, which is a public good" (Greenspan, 1988). If one should recognize that banking is a public good only in the event of crisis - questions arise whether it should be in the event of a system or an individual bank's crisis; what to consider as conditions of crisis; what level of public help is allowed? It seems that the licensed banks should be treated as a public good.

\section{Banking and State Intervention}

W. Bagehot's doctrine $\left(19^{\text {th }}\right.$ century) stipulated that in a bank crisis - the central bank or the government becomes the essential Lender Of Last Resort (LoLR). In compliance with this doctrine, central banks of many countries took the LoLR role on themselves. S. Hefernan thinks that "if LoLR judges that the source of the problem is run or bank panic, not the financial situation of the bank, it may lower its requirements concerning capital adequacy and apply smaller penalty interest rate. As a matter of fact, arguments for LoLR existence resemble nuclear bogeyman: it is a tool that is meant to prevent panic that could happen." (Heffernan, 2007, p. 574). During the subprime crisis FED, ECB and central banks of the EU countries broadly performed LoLR function (Masiukiewicz, 2008). The first institution to take up function of international LoLR was the International Money Fund, by granting credit line for countries affected by financial crisis in the 90'. 
The $20^{\text {th }}$ century was quite rich in banking crises. At the same time, the development dynamics, social reach of banking and attempts to calculate social costs of bankruptcy (E. Altman) were undoubtedly the causes of wide spreading of new doctrines. Ch. James' research indicated that liquidation of insolvent banks is more expensive than its recovery, takeover by healthy bank or even nationalization (James, 1991). E. Gardener and P. Molyneux gave much attention to the "Too Big To Fail" (TBTF) and "Too Important To Fail" (TITF) doctrines (Gardener \& Molyneux 1998). Those authors were proving that due to the importance for the system risk, some banks (so called strategic) deserve rescue by the State (not excluding nationalization), and doctrines TBTF and TITF became practice. (Gardener \& Molyneux, 1998) Opponents of such approach stated, on the other hand, that this certainty about public bailout would lead to strengthening moral hazard.

In the end of the $20^{\text {th }}$ century a new approach appeared in the literature, treating financial stability, as well as the banks themselves as a public good (G. Corrigan, S. Heffernan, P. Krugman, J.K. Solarz, J. Stiglitz); what would justify its bailout during crisis (Masiukiewicz, 2010b).

G. Kaufman defined banking crisis as a situation that is characterized by bank run, financial institutions collapses or massive state intervention as well as broad disruption of safety of other institutions. (Kaufman, 1999) This definition clearly focuses on elements of panic and state help in crisis. System risk and threat of panic epidemic - according to the S. Heffernan are the key causes to the State for having inclination to special treatment of banks, and to central banks for serving as the LoLR or delivering, so called, lifeboat rescue operation (Hefernan, 2007, p. 41).

There are many cases - what is proved by crises history - in which central banks and system regulators were intervening to save individual bank or group of banks; protecting at the same time other entities of the financial system (Hefernan, 2007, p. 209). J.K Solarz claims that the banking crisis (and social response) may even force authorities to intervene and provide significant help to this sector (Solarz, 2008, p.101). Financial crises showed how far governments can go to prevent a bank from collapsing, how broadly the TBTF and TITF doctrines can be applied. (Hefernan, 2007; Gardener \& Molyneux, 1998) As a part of the fight against subprime crisis, the governments and central banks of USA and Europe reached for the most radical measures, including nationalization of financial institutions and using vast funds from taxpayers (Krugman, 2008). Even D. Strauss-Kahn (a former president of the IMF) sided for the interventionism: "necessity of public intervention becomes even more obvious. Government intervention - regardless of whether it's on securities or real estate market or banking 
industry - would act as "third line of defense" supporting the fiscal and monetary policies" (Guha, 2008). In M. Diekmann's opinion (the then president of the Allianz Group) the debate should focus not on whether the state should intervene, but rather on how to do it (Diekmann, 2008).

Also the experience of the Polish banking crisis from the 90's clearly indicate that without subsidies (as a restructuring bonds) and tax reliefs many banks would go bankrupt causing a domino effect, i.e. enterprise bankruptcy.

New measures of the European Commission are an introduction of the CRD/CRR directives that tighten norms of banks operation and preparation of draft of the resolution and recovery regime procedure for big banks - that enables scheduled liquidation; that is to not allowing a sudden collapse (Masiukiewicz, 2013b). A new concept is also a creation of Banking Union as a part of the EU (Masiukiewicz, 2013c).

Also, a question arises about the admissibility of public aid for banks in the EU countries. W. Szpringer points out that the member countries that bailout threatened banks are not only bound by the art. 87-89 of TEC, but also by the instructions of the European Commission regarding the rules of public aid for financial institutions in connection with the global financial crisis. (Szpringer, 2009b, p. 23) One of the forms of States' aid for financial sector are the government guarantees for banks' liabilities. The guarantees relate usually to all retails deposits and selected categories of wholesale deposits as well as medium term debt instruments.

The European Commission has announced new guidelines for recapitalizing financial institutions by governments. They stipulate that the capital aid from the State cannot affect competitive advantage of banks from one member country over institutions from another EU countries (Szpringer, 2009a, p. 24). Implemented in 2008, the European Plan for Economic Recovery, even though it did not bind anyone was treated as additional guideline for admissibility of public intervention aid (Szpringer, 2009a, p. 25). After the subprime crisis many EU countries founded Recovery Funds, also in Poland, the bill on Banking Guarantee Fund (BFG) provides banks with the possibility of receiving aid and credit unions in the form of long term loans for recovery programs in the event of crisis (Masiukiewicz, 2013a).

Economics theorists have recently expressed the need for redefining role of the State in the economy - in the circumstances of global companies and products, global shortages and global crises. G. Rae presents a thesis that the State has to return to the subjective role in the united Europe's economy; also laying out a number of arguments supporting it (Rae, 2008). 
Regarding the banking industry, there are opinions claiming its overregulation by the State. Basel III recommendation and CRD/CRR directives have introduced a number of new limits on banks, and the regulators have rights to accept a president and vice president, to accept shareholders with more that $10 \%$ shares of the bank, to ban selling selected products, may also suspend the bank, liquidate it, or compulsorily merge it with another bank, as well as number of other rights (Masiukiewicz, 2013a).

The new regulations in the European Union went further. The EU Directive in the area of "recovery and resolution regime", which was implemented in 2014-2015 period in member states, created new possibilities of state intervention in banking (Masiukiewicz, 2013b). The possibility of this intervention is advantageous for stability of economics policy.

It is necessary to point out that the consequences of new banking crises may be only comparable to the costs of a nuclear strike; it is estimated that a medium-size banking crisis costs about 15-20 \% GDP - for which taxpayers will pay (Masiukiewicz, 2009).

\section{Arguments For and Against Recognizing Banking as Public Good}

Recently in literature some researchers raise the issue of social responsibility of banks and the costs related to their quasi-social mission. The following are typical costs that banks cover in this area nowadays:

- costs of restructuring bankrupting enterprises,

- risk and costs of premature deposit withdrawal by customers (bank run),

- costs of maintaining customer deposit insurance system,

- crediting endeavors in area of public procurement and public-private partnership,

- granting preferential loans (agricultural, student, environmental and other),

- costs of overdue receivables from public institutions and economic consequences of consumer bankruptcy for banks,

- costs of counteracting financial exclusion that is recommended by authorities (e.g. in EU). 
Figure 1. Amount of bank accounts in the EU per capita in 2011.

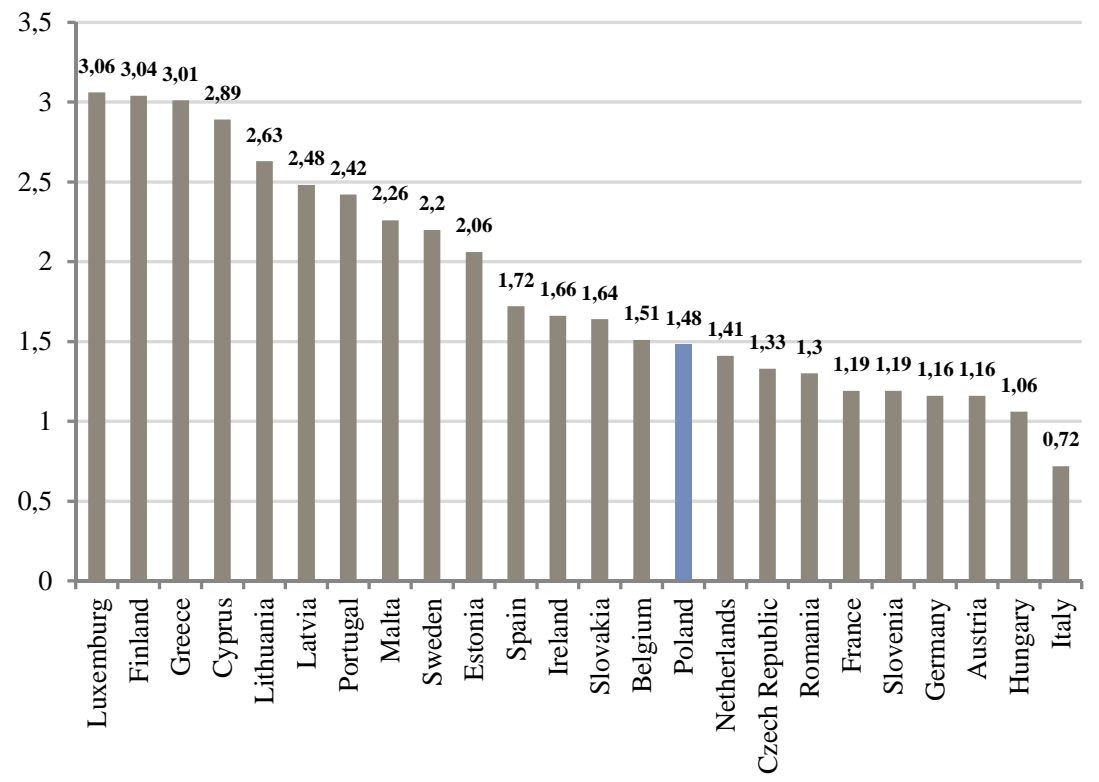

Source: ECB Statistical Data Warehouse (2014), Retrieved from: http://sdw.ecb.europa.eu/ (14.11.2014).

A significant argument for considering banking as a public good is the level of access to and use of banking services. Provided in $19^{\text {th }}$ century 1 $5 \%$ of society had access to financial services, presently in highly developed countries banking access indicator reaches 95\% (in Poland 80\%), and the number of accounts per capita surpassed 1 a long time ago (Figure 1). Highly developed countries implement governmental programs to counteract with financial exclusion - to achieve banking access factor close to $100 \%$. For instance, in some EU countries the central bank may assign the duty to open bank accounts to the homeless and the poor. Presently broad access to financial services, assurance of funds safety, and facilitations in performing transactions and cash flows cause that in highly developed countries it is nearly impossible to function without bank.

New, characteristic circumstances of modern banking functioning indicate its risks and its role in maintaining financial stability, therefore also indicate the need for public protection. New opportunities and threats for banking industry are presented in Table 1 . 
Table 1. Opportunities and threats of modern banking

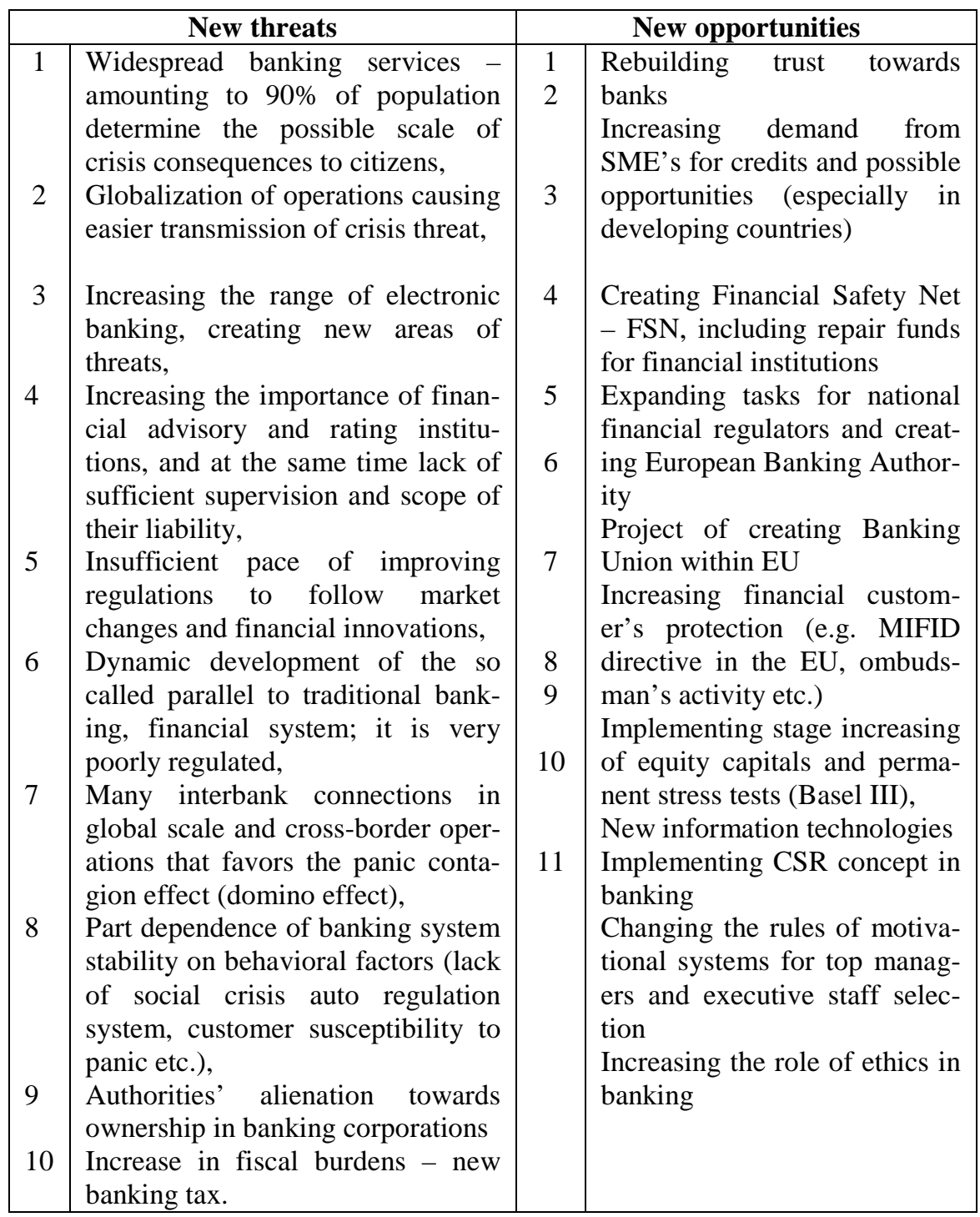

Source: own work.

Growth financing, safety of citizen and corporate savings, development of international exchange are served by banks and therefore dependent on bank's standing and more broadly on credit-depository institutions' standing. 
Elementary arguments for treating banks as a public good are the following (Masiukiewicz, 2010a, Masiukiewicz, 2010b):

- functions of banks that ensure economy and households growth,

- special legal regulations and licensing of banking activity (de Larosierere report that was accepted by the European Commission recommended increasing regulations after subprime crisis),

- public trust as the operation attribute (strengthened institutionally by the State),

- public deposit insurance system,

- setting many market parameters for banks by the State (reference interest rates, reserve ratio, maximal interest rate for consumer credits etc.),

- broad supervisory rights for regulators; broadened even further towards banks in a critical situation (orders and bans for banks),

- performing state delegated functions and function of restructuring overdue liabilities of enterprises and households by selected banks,

- operations openness, mass media access to the information - which may in special cases be used against the bank,

- banks' high sensitivity for crises and contagion effect (therefore a possible influence on destabilization of a whole financial system),

- system of public institutions appointed to protect financial customers (financial supervisors, deposit insurance fund, bank customers' ombudsman, compulsory administration and other),

- bearing the costs of maintaining financial safety net, as well as the costs of bank bankruptcies by taxpayers - customers.

One can also lay out number of arguments against it, among others they are:

- functioning in free market,

- customer's freedom of choosing a bank,

- general prohibition of granting public aid for enterprises in the EU (although with exceptions),

- risk of political pressure concerning scope and structure of public aid for banks,

- moral hazard of management; granting public aid to bank was not always connected with consequences for then top managers.

The problems connected with the matter of concerning banks as a public good and consequences of public aid require further research and discussion. Yet, in the end, it will be up to national and European authorities to decide on voters' behalf about the approach and policy regarding this matter. 


\section{Conclusions}

Common access to banking, its role in financing a country's development and at the same time experiences from a number of international crises and bank bankruptcies indicate broad social consequences of possible bankruptcies and justify applying the doctrine of concerning banking as a public good and state intervention connected with that.

As a consequence of treating banking as a public good perhaps it ought to function in the citizen's interest, be under protection and supervision of the State. It also means limiting the market's influence on this industry, the possibility of providing services by the State industry or nationalizing part of the banking industry in a financial crisis. Operations of banks should be based on the Corporate Social Responsibility (CSR) concept.

Treating banking as a public good creates a social and economic justification for:

- strengthening public trusts towards banks,

- state co-financing of deposit insurance system,

- using financial supervisory and regulatory instruments in the interests of the citizens,

- building national and European Financial Safety Net (FSN) and providing aid to the banks in critical situation,

- ensuring common access to financial services (elimination financial exclusion).

Further research of problems connected with the issue presented in this article should among other things answer following questions: how strongly regulated banking industry should be, what instruments of restructuring should be used during system crisis and what are the limits of growth of big global banks and who should supervise them. Protection of financial safety of households and enterprises should be the main goal and criterion of State policy in the discussed matter.

\section{References}

ECB. Statistical Data Warehouse. (2014), http://sdw.ecb.europa.eu/ (15.09.2014). Buchanan, J. M. (1968). The Demand and Supply of Public Goods. Chicago: Rand Mc Nally.

Corrigan, G. (1992). Challenges Facing the International Community of Bank Supervisors. Quarterly Review, Federal Reserve Bank of New York, Autumn.

Diekmann, M. (2008). The Swing to the State Must Not Go Too Far. Financial Times, 22.12. 
Fijor, J. M. (2011). Czy dobra publiczne są naprawdę publiczne?. Studia Ekonomiczne, 1.

Gardener, E. P. M., \& Molyneux, P. (1998). Powrót do doktryny TBTF: postępowanie wobec banków strategicznych zagrożonych upadłością. Bezpieczny Bank, 1.

Greenspan, A. (1988). Testimony Before the Committee on Banking. Housing and Urban Affairs, 02.02.

Guha, K. (2008). IMF Head Calls for Global Action on Turmoil. Financial Times, 07.04 .

Heffernan, S. (2007). Nowoczesna bankowość. Warszawa: PWN.

James, C. (1991). The Losses Realized in Bank Failures. Journal of Finance, 9.

Kaufman, G. G. (1999). Banking and Currency Crisis: a Taxonomy and Review. Loyola University of Chicago Working Paper, No 11.

Krugman, P. (2008). Brown Des Good. New York Times, 12.10.

Masiukiewicz, P. (2009). Kryzys banku a interwencje państwa. In: I. Lichniak (Ed.). Wyzwania ekonomiczne w warunkach kryzysu, Warszawa: Oficyna Wydawnicza SGH.

Masiukiewicz, P. (2010a). Crisis Threat and Banking Reform Trends. Perspectives of Business, Innovations, Economics Journal, 6. http://dx.doi.org/10.152 08/pieb.2010.78.

Masiukiewicz, P. (2010b). Doktryna dobra publicznego w bankowości. Prakseologia, 150 .

Masiukiewicz, P. (2013a). Management of Financial Safety Net in Poland, Management Trends in Theory and Practice, Scientific Papers. Faculty of Management Science and Informatics, Institute of Management by University of Zilina.

Masiukiewicz, P. (2013b). Recovery and Resolution Regime in Polish Financial Market. In: J. Grzywacz, \& S. Kowalski (Eds.). Banki, przedsiębiorstwa i społeczeństwo w warunkach niepewności. Płock: Wydawnictwo PWSZ.

Masiukiewicz, P., \& Dec, P. (2013). Dysfunctions and Risks of Big Financial Institutions. Business Systems and Economics, Research Journal, 3.

Masiukiewicz, P. (2014). Funkcja sanacyjna banków wobec przedsiębiorstw. In: S. Flejterski, \& A. Gospodarowicz (Eds.). Banki w społecznej gospodarce rynkowej. Warszawa: Wyd. Związek Banków Polskich.

McNutt, P. A. (2002). The Economics of Public Choice, $2^{\text {nd }}$ ed., Cheltenham, UK and Northampton, USA: Edward Elgar.

Rae, G. (2008). Państwo musi wrócić do podmiotowej roli w gospodarce zjednoczonej Europy. Le Monde Diplomatique, 8.

Samuelson, P. A. (1954). The Pure Theory of Public Expenditures. Review of Economics and Statistics, 1. http://dx.doi.org/10.2307/1925895.

Krajewski, W., \& R., Banajski (Eds.) (1996). Stownik filozoficzny. Warszawa: Wydawnictwo Naukowe Scholar.

Solarz, J. K. (2008). Zarzadzanie ryzykiem systemu finansowego. Warszawa: PWN. Szpringer, W. (2001). Bezpieczeństwo systemu bankowego. Warszawa: Twigger. 
Szpringer, W. (2009a). Społeczna odpowiedzialność banków. Między ochrona konsumenta a ostona socjalna. Warszawa: Oficyna Wolters Kulwer.

Szpringer, W. (2009b). Kryzysy a pomoc publiczna dla banków w UE. In: P. Masiukiewicz (Ed.). Międzynarodowe bankructwa i afery bankowe. Warszawa: Oficyna Wydawnicza SGH. 

